\title{
Models to Inform Capstone Program Development
}

\author{
Nicole A. Buzzetto-More \\ University Maryland Eastern Shore, Princess Anne, MD, USA
}

\author{
Nabuzzetto-More@umes.edu
}

\begin{abstract}
A capstone course is a transformative educational experience predicated on student-centered pedagogy. In a capstone experience learners are required to apply higher-order thinking, authentic learning, and multilayered decision-making while engaged in an experiential learning activity.

Allowing students to make autonomous decisions regarding the direction of learning, capstones are offered near the conclusion of a program of study and are organized around a comprehensive, intensive and integrative project. The methodology employed in the completion of these projects is purposeful so as to satisfy multiple targets (e.g. educational objectives that a student is expected to have mastered). The outcome of which is an opportunity for students to showcase knowledge, skills, and abilities in a unique and individualized manner.

The following paper reviews the literature on capstone-based instruction assessment in the United States, and introduces models designed to inform capstone program development. Finally, a State-wide capstone course developed for high school students in Maryland is discussed.

Keywords: capstone, capstone assessment, capstone model, senior project, summative assessment, project based learning, experiential learning, student centered teaching, career and technology education, vocational education, K-12 assessment, project based learning, flexible learning, learning outcomes
\end{abstract}

\section{Literature Review}

Capstones are a superior venue for assessing learning (Wagenaar 1993), while involving students in experiences that transcend the restrictive boundaries associated with traditional curricula (Lopez, 2005). During capstone experiences, students go through an extended process of inquiry in response to a complex question, problem, or challenge. Students evaluate these complexities from a variety of angles in a manner that respects individual learning styles (Moursund, 1999). Learners demonstrate the ability to plan, select, and locate information; engage in critical analysis; apply multilayered decision making; and generate new meaning (Page, 2006). As a result, students are able to assimilate, assess, and apply knowledge, in a way that demonstrates mastery while building deeper levels of understanding (Berheide, 2012, O'Grady, 1999).

Material published as part of this publication, either on-line or in print, is copyrighted by the Informing Science Institute. Permission to make digital or paper copy of part or all of these works for personal or classroom use is granted without fee provided that the copies are not made or distributed for profit or commercial advantage AND that copies 1) bear this notice in full and 2) give the full citation on the first page. It is permissible to abstract these works so long as credit is given. To copy in all other cases or to republish or to post on a server or to redistribute to lists requires specific permission and payment of a fee. Contact Publisher@InformingScience.org to request redistribution permission.
Capstone courses can be offered fully online, through face-to-face classroombased learning, or hybrid where physical classes and technology enhanced learning are combined. Whether technology is used to facilitate, enhance, or totally deliver a capstone experience, the number of technological tools available is numerous. Examples include: simulations; spreadsheets; research databases; 
multi-media publishing tools; blogs and wikis; e-portfolio systems; brainstorming and modeling software; computer aided design systems; cloud computing; remote sensing and tele-robotics; learning management systems; open-source instructional tools; presentation software; Web conferencing systems; virtual worlds; digital storytelling tools; voice threads; mobile technologies; social bookmarking services; communication and collaboration systems; podcasts; avatars and etcetera.

Regardless of the delivery method, capstone experiences can be designed to help learners:

- Understand the connection between curriculum and learning objectives,

- Reflect on what they have learned as a result of completing a program of study,

- Visualize the application of learned knowledge and skills to the workplace,

- Engage in interdisciplinary understanding,

- Reflect on the issues involved in the transition into their next phase of education and/or their professional career,

- Build life-long learning skills,

- Connect general education to discipline specific curriculum,

- Develop the capabilities desired by future employers (Gardner et. al., 1998, pp.301-302).

Results from the National Survey of Student Engagement Report (2007), report that capstone experiences increase overall student performance. Additionally, data indicates that capstone experiences may serve as an equalizer that offers all students, from low to high achievers, an opportunity to succeed. Further, they have been found to be particular effective with socially disadvantaged and at-risk students (Buzzetto-More \& Mitchell, 2009).

Capstone experiences are linked to a number of positive pedagogical concepts. These include: guided inquiry, self-directed learning, information literacy, technological fluency, constructivism, higher order thinking, individualized instruction, metacognition and reflective thinking, elearning, flexible learning, project-based learning, interdisciplinary thinking, core knowledge, and authentic assessment, (Kulthau \& Todd, 2007; Page, 2006; Kannapel, 2012; Buzzetto-More, 2012). Holdsworth, Watty, and Davis (2009) explain that while most capstone activities are well established practices, they are treated with new approaches and greater significance when incorporated in a capstone experience.

Capstone experiences are fairly common in higher education. An evaluation of 707 regionally accredited colleges and universities found that almost $1 / 2$ use capstones as part of institutional assessment programs (Henscheid, 2000). Additionally, a national study of community colleges (Clark, Engel, Napolitano, Richardson, Rodriquez, Sterling-Deer, \& Kasprzak, 2008) concluded that capstones represent the most comprehensive educational experience possible supporting the assessment of both core competencies and discipline specific objectives.

Weiss (2002) examined the perceptions of sociology department chairs finding that work done in a capstone course rates as one of the most valuable assessment tools available. Also, Moriarty (2006) reported that $51 \%$ of programs rated capstones highest in effectiveness. Finally, Black and Hundley (2003) explained that capstone-based assessments provide valuable information to faculty and administrators regarding the overall quality and effectiveness of instruction (Black \& Hundley, 2003).

High school capstone experiences were discussed in a number of publications and reports dating as far back as the 1990's (Regional Educational Laboratory Northeast \& Islands, 2009). In 2002, the U.S. Partnership for 21st Century Skills (2013) identified the need for schools to incorporate problem solving; information and technical literacy; communications; and critical thinking into high school curricula. Further, the recent Common Core State Standards Initiative has emphasized the need to enhance the career and college readiness of high school graduates (National 
Governors Association, 2010). In order to be in compliance with 21st Century Skills and Common Core requirements, Burke (2011) opined that capstone experiences should be embedded in all career and technical education (CTE) programs.

Capstone courses are rare in American K-12 education; however, adoption of capstone experiences has been growing steadily, albeit slowly, during the past decade. While limited research exists, a survey of 422 graduates who had completed a capstone experience, found that most $(>75 \%)$ of participants reported developing skills in public speaking, research, writing, interviewing, planning, time management, and interpersonal communications (Egelson, Harmon, \& Bond, 2002). Additionally, a recent survey found that capstones enhance the college and career readiness of learners (North Carolina General Assembly: Program Evaluation Division, 2010).

The pioneer of public K-12 capstone experiences is the State of Rhode Island. Under the Rhode Island Diploma System, students demonstrate proficiency through multiple sources of evidence gathered over time. State assessment results count for no more than 10 percent of this evidence. Other factors considered include: portfolios, capstone projects, public exhibitions, and the State's Certificate of Initial Mastery. As the culminating achievement of a student's K-12 studies, the Rhode Island Capstone Project requires students to focus in-depth on a core question, the product of which plays an essential part in demonstrating that a student meets graduation standards (Rhode Island Skills Commission, 2012).

Tennessee also has a capstone option. Introduced in 2009, a capstone project is recommended, but not required, for seniors. Requirements are determined locally and may include, but are not limited to, senior projects, virtual enterprises, internships, externships, work-based learning, service learning, and/or community service. Capstone projects must have five core components: (1) an approved proposal containing the research question; (2) documented research and contact hours with a mentor; (3) a short written paper; (4) an oral presentation that demonstrates the research and knowledge learned; and (5) a review panel to evaluate the project (Tennessee Department of Education, 2008).

Virginia is currently piloting senior year capstone courses in English language arts and mathematics that are designed to help students master the State's college and career readiness expectations. Also, in the pilot stage is the Connecticut's Capstone Experience, which will be required of all students effective with the class of 2020 (Kannapel, 2012). Finally, North Carolina provides guidance and assistance to local districts that would like to introduce a capstone project. As such, $69 \%$ of North Carolina high schools require students to complete a capstone project (North Carolina General Assembly: Program Evaluation Division, 2010). According to State guidelines, projects must include a research paper, product, portfolio, and an oral presentation (Kannapel, 2012).

Development of capstone courses is a complex process and yet a lack of practical models exist to help steer the conceptualization, fabrication, and maturation of capstone programs. The scarce models that are available models tend to focus on the student processes involved. For example, the model introduced Andraesen (2004) depicted in Figure 1 focuses on the intersection of experiential elements into the capstone experience. 


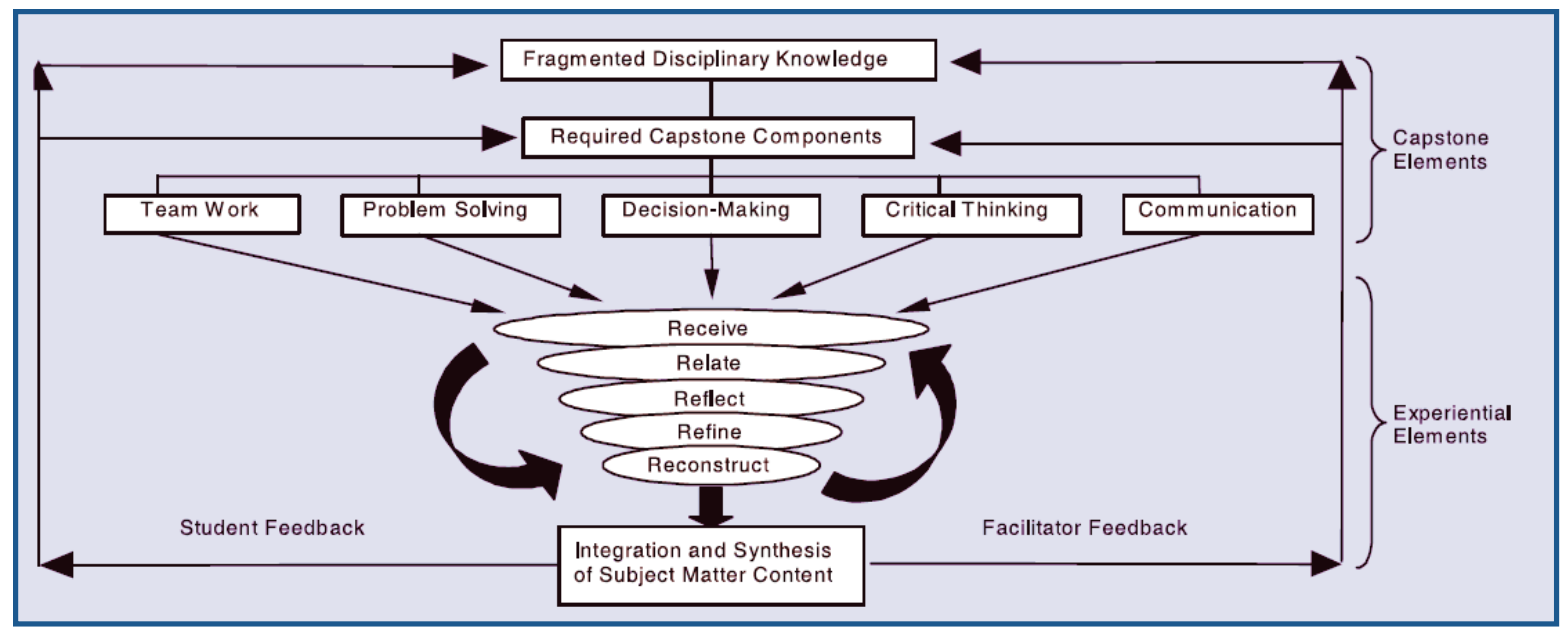

Figure 1: Model for the Integration of Experiential Learning into Capstone Courses (Andreasen, 2004).

The North Carolina Graduation Project Model (2010) depicted in Figure 2 is designed to inform the K-12 community. The model considers the inputs, activities, stakeholder involvement, output, and short and long term outcomes that should be involved in a capstone program

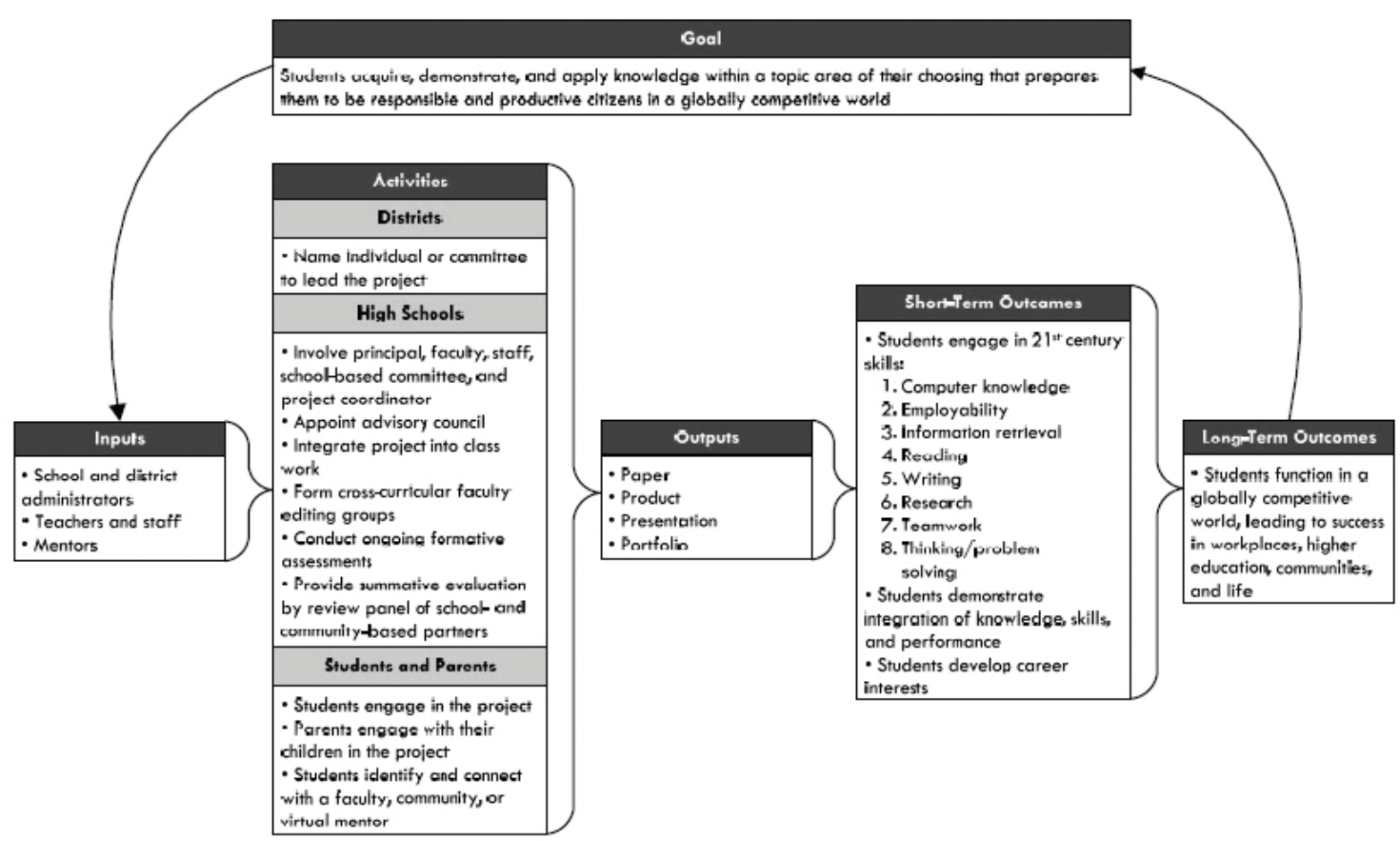

Figure 2: North Carolina Graduation Project Model

Holdsworth, Watty, and Davies (2009) introduced a series of guided questions designed to serve as a model for capstone program planning. Known as the Melbourne Model, these questions are included in Figure 3 
WHAT IS A CAPSTONE EXPERIENCE

Dependent on whether it will be disciplinary or interdisciplinary, the desired outcomes, and the supported activities.

REASONS FOR DEVELOPMENT

In relation to the overall course or program.

AIMS OF THIS CAPSTONE EXPERIENCE

In terms of student learning outcomes?

TEACHING APPROACHES

What teaching approaches will be employed, will it be course based, what activities will be included (pro-

jects, internship, examinations, simulations, projects, field work, service, immersion, etcetera)

STUDENT LEARNING OUTCOMES

Learning Outcomes to be built and assessed.

RESOURCES NEEDED

Important to identify gaps and deficiencies.

CAPSTONE ASSESSMENT

What will be assessed and how will it be assessed?

STUDENT AND STAKEHOLDER EVALUATION

What will be the most meaningful way to gather student and other stakeholder feedback and how will it be used to make curriculum improvements?

Figure 3: Melbourne Model (Holdsworth, Watty, \& Davies, 2009).

Capstone programs are almost always introduced in order to engage students in a deeper level of learning, not normally found in a traditional classroom (Lopez, 2005). Yet, many capstone programs fall short of their intended goals. After having to temporarily suspend their State-wide capstone, North Carolina identified the key elements requisite for program success. They included:

$\checkmark$ A model for quality assurance and consistency,

$\checkmark$ Training and information resources,

$\checkmark$ Pilot sites,

$\checkmark$ Stakeholder engagement,

$\checkmark$ Centralized support for training, leadership, and information dissemination, and

$\checkmark$ A means to evaluate the success of the program.

(North Carolina General Assembly: Program Evaluation Division, 2010).

The dearth of implementable models has led to poor planning, which has resulted in the early demise of many capstone initiatives. A model is introduced in the next section that seeks to inform those individuals and/or institutions interested in introducing and implementing a comprehensive capstone program.

\section{Discussion}

In 2009 it was decided by the Maryland State Department of Education (MSDE), under the advisement of the State Advisory Committee, that a capstone experience would be added to the Business, Management, and Finance (BMF) high school completer programs in Maryland. A model, represented in Figure 4 has been developed that represents all process both completed as well as planned. 


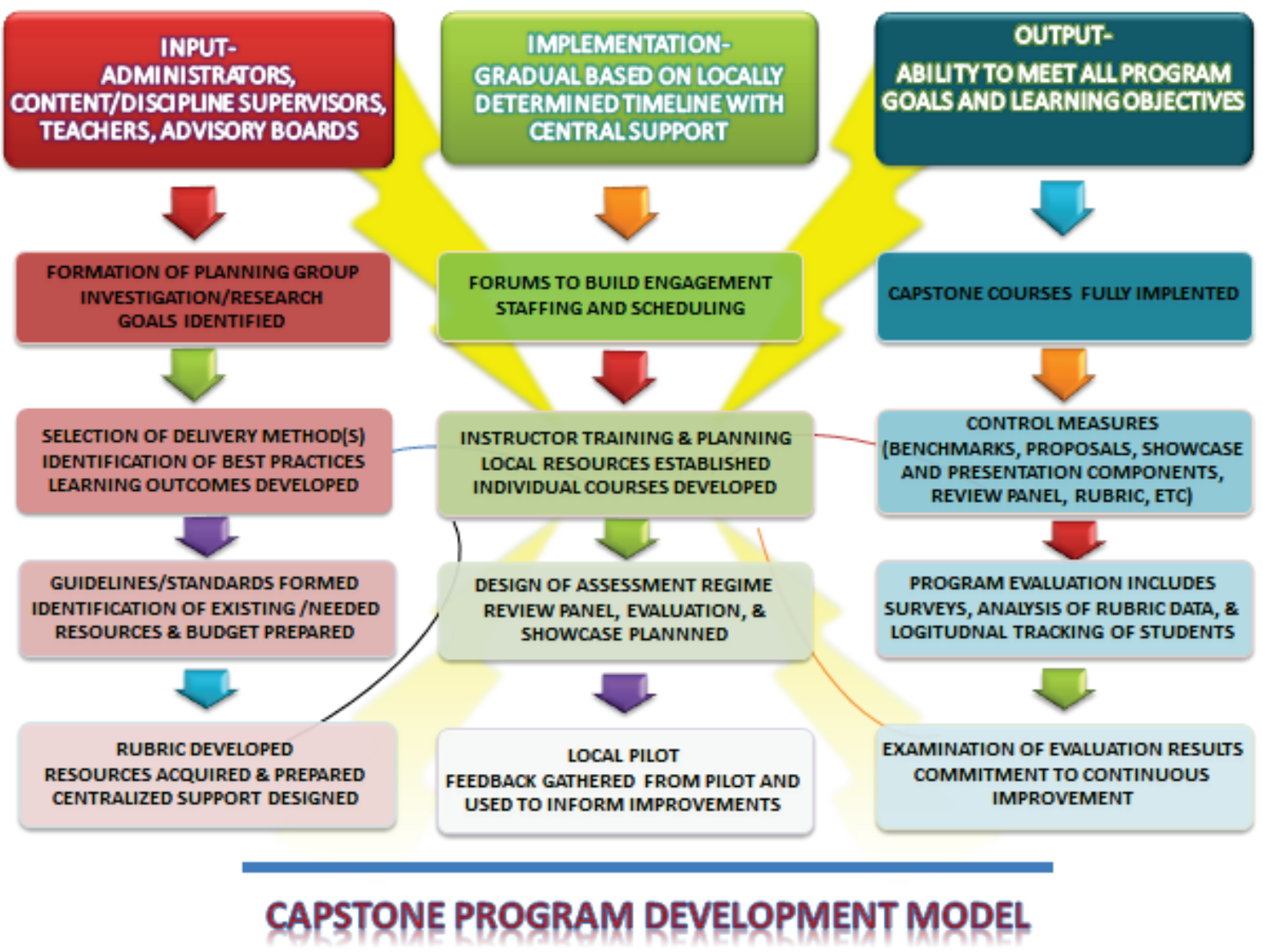

Figure 4: Capstone Development Model

According to the model, capstone program development begins with input from all stakeholders, which includes the establishment of a planning and development group with representatives from applicable stakeholder groups. Processes include identification of: desired program goals; student learning outcomes; learning delivery options; existing and required resources; support services; desired practices; model with guidelines and standards; and assessment instrumentation.

During this project, a wide net was cast, the literature was reviewed, and a number of models were examined. In particular, the Memphis City Schools, Rhode Island, University of Maryland Eastern Shore, University of Hawaii at Manoa, Skidmore College, and the Tennessee Public Schools capstone experiences were examined. Following the review, it was determined that a credit bearing capstone course offered greater pedagogical advantages to both teachers and students than a stand-alone capstone experience or project could avail. The curriculum development team comprised of MSDE BMF Cluster Staffers and the MSDE BMF Program Affiliate Director, with feedback from the State Advisory Council, identified the best practices in capstone instruction. These best practices informed the development of the capstone course. They are represented in Figure 5. 


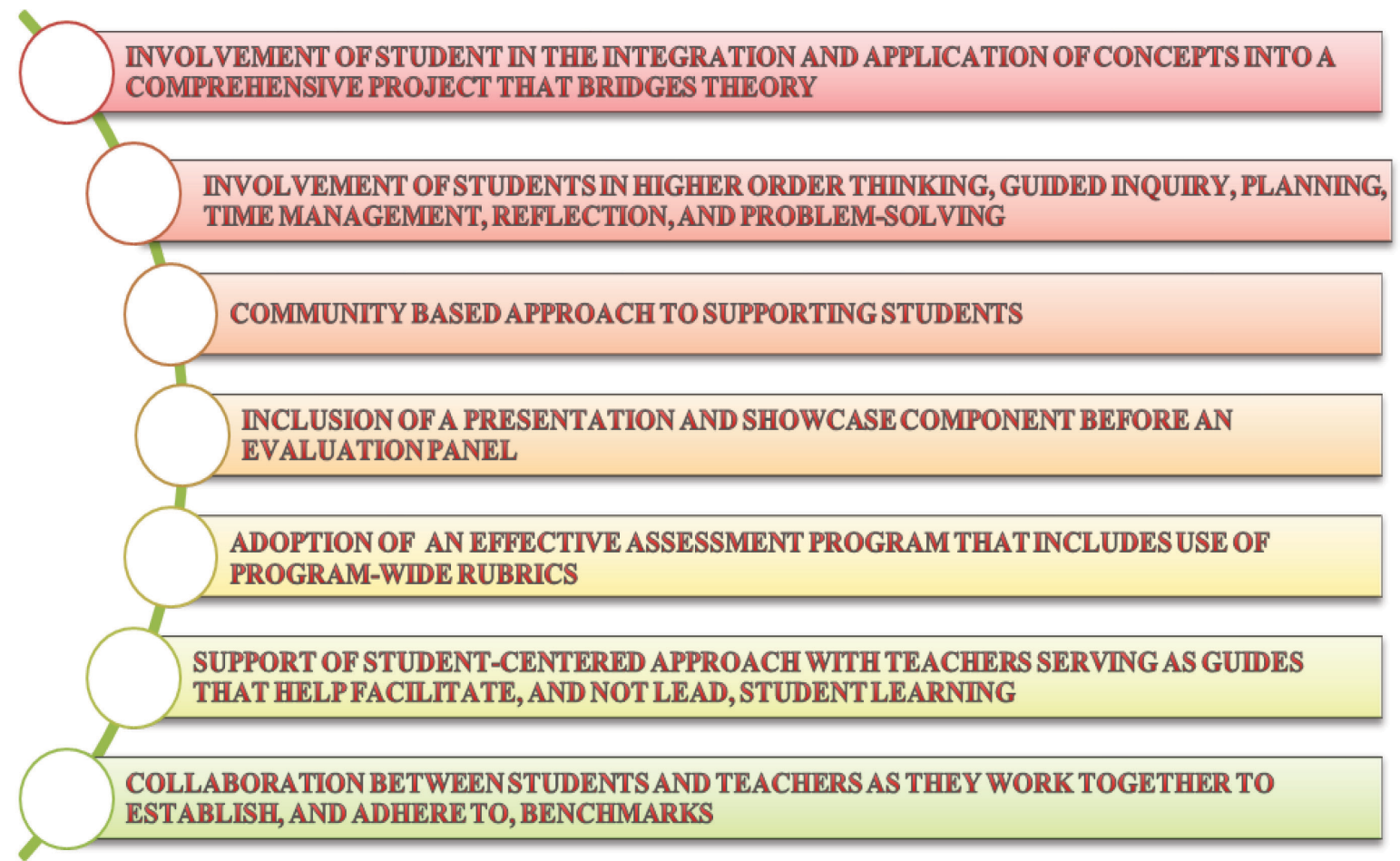

Figure 5: Best Practice in Capstone-Based Instruction (Buzzetto-More, 2013)

There are seven identified best practices:

1. Involvement of students in the integration, and application of key concepts into a comprehensive project that bridges theory with practice

a. Identification of the application of program learning objectives must be done before a student commences work on his/her capstone project.

2. Involvement of students in higher-order thinking, guided inquiry, planning, time management, reflection, and problem-solving

a. Students locate, compare, classify, sequence, analyze, plan, schedule, reflect, hypothesize, synthesize, evaluate, associate, modify, and defend.

3. Community-based approach to supporting students

a. Students should be supported by discipline teachers as well as by professional practitioners. Additionally, guidance from university, college, and/or community college faculty with content expertise is also a recommended practice.

4. Inclusion of a presentation and showcase component before an evaluation panel

a. Students should be required to present their project in front of their classmates as well as in front of a review panel. While capstone projects can be displayed within the confines of a classroom, a best practice is the establishment of a formal event that celebrates student achievement by showcasing all completed projects simultaneously.

5. Adoption of an effective assessment program that includes program-wide rubrics

a. Rubrics communicate expectations and standards of performance. They establish criteria for consistent grading with the use of descriptive performance levels along a meaningful spectrum (Buzzetto-More, 2007). During this project, a number of capstone rubrics were examined, including the one from Rhode Island (Rhode Island Skills Commission, 2012). As a result, a holistic rubric was developed, presented in the Appendix. 
6. Support a of student-centered approach with teachers serving as guides that help facilitate, and not lead, learning

a. The capstone teacher supports, without leading, as he/she establishes the necessary structure to guide, inspire, and monitor students (University of Hawai'at Mānoa, 2010).

7. Collaboration between students and teachers as they work together towards benchmarks

a. Students are required to be an active participant in the learning process by selecting their topic, developing a project proposal, scheduling activities, selecting resources, and identifying tasks. At the same time, students should not be forced to work in isolation.

Program goals, procedures, and the desired student experience were identified. This information is depicted in the model represented in Figure 6 where participating students are informed by, and receive input from, peers, teacher(s), guides, requirements, and the larger community. During the throughput process, students engage in brainstorming, discovery, analysis, planning, scheduling, proposal development, critical thinking, synthesis of ideas, showcase and defense, and reflection. Quality controls include the use of benchmarks and formative evaluation. The output is student mastery of learning objectives as indicated through an exemplary project.

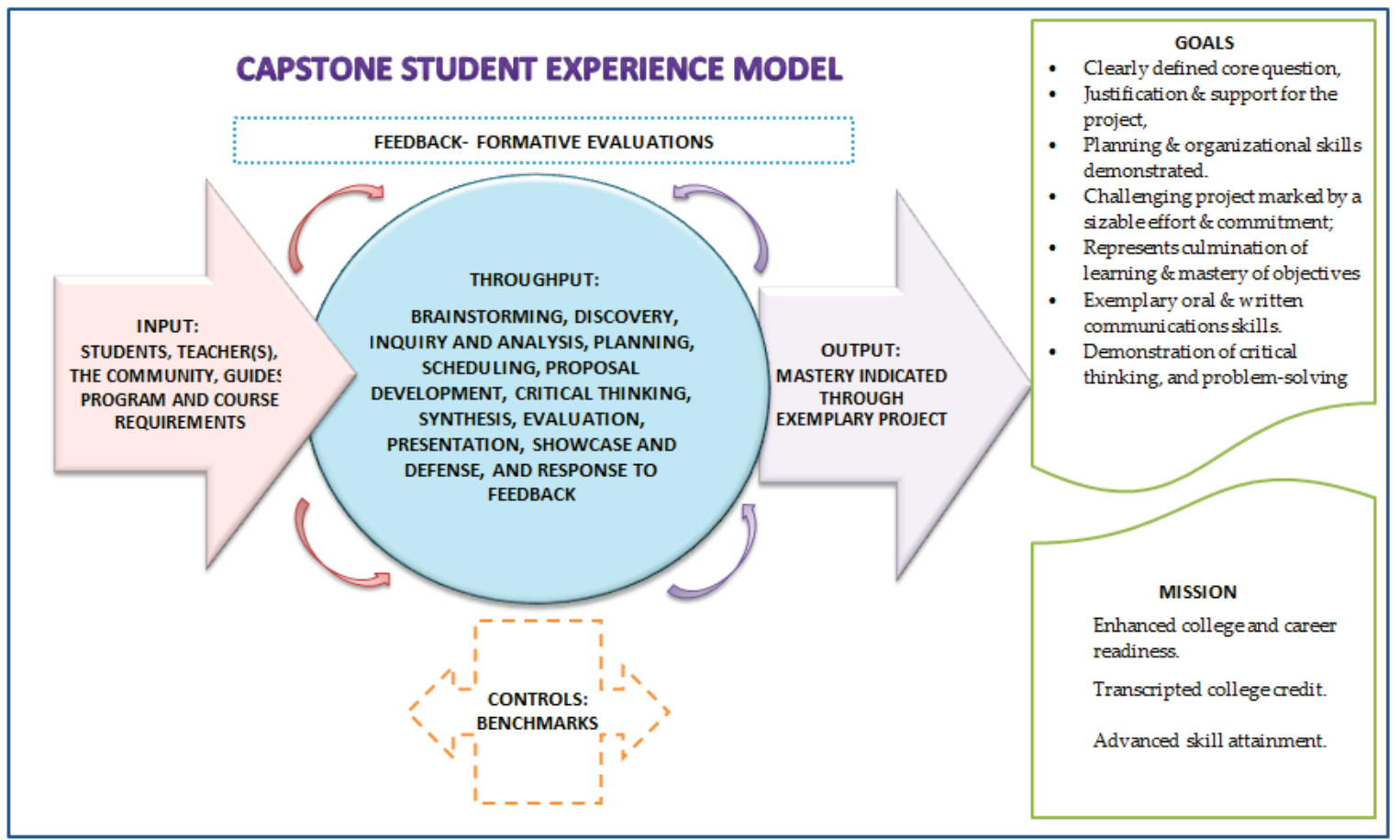

Figure 6: Student Capstone Experience Model

During program implementation, processes include course scheduling and staffing, instructor training and planning supported by resources, and forums held to build stakeholder engagement. Also, crucial to program implementation is testing with a pilot group, followed by program modifications/enhancements. The Maryland State-Wide BMF Capstone Project is currently in the implementation stage. Teachers and students are supported through a host of resources, among which are custom developed guidebooks. Presentations are being made to teachers and administrators across the State in conjunction with meetings, training workshops, and professional conferences. Additionally, a course is currently under-development to be offered in fully online and hybrid learning formats. The course will be made available exclusively to teachers in Maryland and will result in the earning of professional development credits. Topics to be covered include: 
flexible education, project-based learning, technology tools, best practices in capstone course delivery, and student learning outcomes assessment.

The output of a capstone program is fully implemented capstone courses that meet all program goals and objectives. Quality control processes support program success and continuous evaluation supports an assurance of learning commitment. The Maryland State-Wide Capstone Project has not reached the output stage; however, student performance data including college acceptance, freshmen retention, and college graduation rates will be examined. Additionally, student and teacher surveys will be developed designed to measure satisfaction with the capstone experience as well as perceptions of value added.

\section{Concluding Thoughts}

Teaching a capstone course is an exciting and ever changing experience. It requires an ongoing and meaningful dialogue to occur between tutor and tutee, the unique nature of which stimulates learning in a way that is without parallel. Teachers express concern that increased student autonomy will result in difficulties in learning management; however, the literature confirms that increased student control over learning results in greater motivation and self-determination (McCombs, 2007).

Well developed and successfully implemented capstone experiences have enumerable benefits as they promote active learning. With careful planning, a student-centered approach, and adherence to the best practices in capstone assessment, capstone courses can serve as highly effective and easily implementable assessment regime that bridge theory with practice.

The success or failure of this project will be examined and reported. The information to be collected will be reported in a future paper. It is the goal that sharing the experiences involved with the design and implementation of this project, as well as the resulting outcomes, will provide useful information to schools interested in exploring a capstone experience as an authentic studentcentered assessment option.

\section{References}

Andreasen, R.J. (2004). Integrating experiential learning into college of agriculture capstone courses: Implications for practitioners. NACTA Journal, 48(1), 52-57

Andreasen, R., \& Trede, L. (2000). Perceived benefits of an agricultural capstone course At Iowa State. NACTA Journal, 44(1), 51-56

Bauer, K. W., \& Bennett, J. S. (2003). Alumni perceptions used to assess undergraduate research experience. Journal of Higher Education, 74, 210-230.

Berheide, C. W. (2012). Using the capstone course for assessment of learning in the sociology major. Skidmore College. Retrieved 9/1/2012 from: http://cms.skidmore.edu/assessment/Handbook/capstonecourse-for-assessment.cfm

Black, K. E., \& Hundley, S. P. (2004). Capping off the curriculum. Assessment Update, 16(1), 3.

Burke, S. (2011, October). A $21^{\text {st }}$ century how to model for CTE programs. Techniques, 87(7), 31-34.

Buzzetto-More, N. (2007, April). Using rubrics to enhance assessment. Proceedings of the 2007 MBEA Conference. Ocean City, MD

Buzzetto-More, N. (2009). Using project based learning to build information and technological literacy. In M. Leaning (Ed), Issues in information and media literacy (pp. 51-74). Santa Rosa: CA, Informing Science Press. 
Buzzetto-More, N. (2010). Use of e-portfolios for value added assessment. In N. Buzzetto-More (Ed.), The E-Portfolio paradigm: Informing, educating, assessing, and managing effectively with e-portfolios (pp. 256-279). Santa Rosa: CA, Informing Science Press.

Buzzetto-More, N. (2012). Maryland BMF Programs of Study: Capstone guide. Baltimore, MD: Maryland State Department of Education.

Buzzetto-More, N. (2013). Fostering flexible education through high school capstone courses. Proceedings of the 2013 SITE Conference. March 25-29 $9^{\text {th }}$, New Orleans, L.A.

Buzzetto-More, N., \& Mitchell, B. (2009). Student performance and perceptions in a web-based computer simulation. Interdisciplinary Journal of E-Learning and Learning Objects, 5, 74-90

Buzzetto-More, N., \& Pinhey, K. (2007, August). Web-based assessments with capstone business students. Proceedings of the 2nd UMES Office of Instructional Technology E-Learning Symposium. Princess Anne, MD

Clark, E., Engel, D., Napolitano, M., Richardson, J., Rodriquez, M., Sterling-Deer, C., \& Kasprzak, C. (2008). Integration reflection, closure \& transition advancing capstone learning at LaGuardia: Report of the faculty research team. Retrieved 9/11/2012 from:

http://faculty.lagcc.cuny.edu/ctl/resources/pdfs/Faculty\%20Research\%20Team\%20Report $\% 20$ on $\% 20$ Capstone\%20Courses 11.18.08.pdf

Egelson, P., Harman, S., \& Bond, S. (2002). A preliminary study of senior project programs in selected southeastern high schools. Annual Meeting of the American Educational Research Association. New Orleans, LA

Gardner, H. (1999). The disciplined mind: What all students should understand. New York, N.Y: Simon \& Shuster.

Gardner, J. N., Van der Veer, G., \& Associates. (1998). The senior year experience: Facilitating reflection, integration, closure and transition. San Francisco: JosseyBass.

Henscheid, J. M. (2000). Professing the disciplines: An analysis of senior seminars and capstone courses (Monograph No. 30). University of South Carolina, Resource Center for the $1^{\text {st }}$ Year Experience. Columbia, SC

Holdsworth, A., Watty, K., \& Davies, W.M. (2009) Capstone experience report. Faculty of Economics and Commerce University of Melbourne. Retrieved 2/1/13 from:

http://w1.tlu.fbe.unimelb.edu.au/papers/academic_resources/Capstone.pdf

Kannapel, P. (2012). High school capstone course: A Review of the literature. Appalacia Regional Comprehensive Center. Retrieved 10/3/2012 from: http://www.edvantia.org/publications/arcc/ARCC_Capstone_Lit_Review.pdf

Kuhlthau, C., \& Todd, R. (2007). Guided inquiry. Retrieved 9/10/07 from http://www.cissl.scils.rutgers.edu/guided_inquiry/implementation.html

Lopez, L. (2005). Senior project: Effectiveness study in North Carolina. Year Two (2004-2005) Final Report. Chapel Hill, NC

McCombs, B. L. (2007). Balancing accountability demands with research-validated, learner-centered teaching and learning practices. In C. E. Sleeter (Ed.), Educating for democracy and equity in an era of accountability (pp. 41-60). New York: Teachers College Press.

Moriarty, L. J. (2006). Investing in quality: The current state of assessment in criminal justice programs. Justice Quarterly, 23,409-427.

Moursund, D. (1999). Ten powerful ideas shaping the present and future of IT in education. Learning and Leading with Technology, 27(1).

National Governors Association. (2010). Common Core State Standards. National Governors Association Center for Best Practices, Council of Chief State School Officers, Washington D.C. 
National Survey of Student Engagement Report. (2007). Experiences that matter: Enhancing student learning and success. Indiana University Center for Postsecondary Research. Press Release.

North Carolina General Assembly: Program Evaluation Division. (2010). Final report to the joint legislative program evaluation oversight committee. Report Number 2010-01.

O'Grady, A. (1999). Information literacy skills and the senior project. Educational Leadership, 57(2), 6162.

Page, D. (2006). 25 tools, technologies, and best practices. T. H. E. Journal, 33(8). Retrieved from http://thejournal.com/articles/18042

Rhode Island Skills Commission. (2005). Capstone toolkit. Retrieved 7/30/2012 from: http://www.ride.ri.gov/highschoolreform/dslat/pdf/exh_050103.pdf

Regional Educational Laboratory Northeast \& Islands (2009, March 11). School redesign-Capstone culminating projects. U.S. Department of Education, Institute of Education Sciences. ED-06-CO-0025. 5 pages.

Tennessee Department of Education (2008). The capstone project: State of Tennessee. Nashville, TN: Author. Retrieved January 31, 2012 from: www.tnelc.org/DownloadFiles/CapstoneManual.doc

University of Hawai'i at Mānoa. (2010). Capstone experiences. Retrieved 7/20/2012 from http://manoa.hawaii.edu/assessment/howto/capstone.htm

U.S. Partnership for $21^{\text {st }}$ Century Skills. (2011). Framework for $21^{\text {st }}$ century learning. Washington D.C. Rertrieved 1/14/13 from http://p21.org/storage/documents/1. p21 framework 2-pager.pdf

Wagenaar, T. C. 1993. The capstone course. Teaching Sociology, 21,209-214.

Weiss, G. L. 2002. The current status of assessment in sociology departments. Teaching Sociology, 30, 391-402.

\section{Biography}

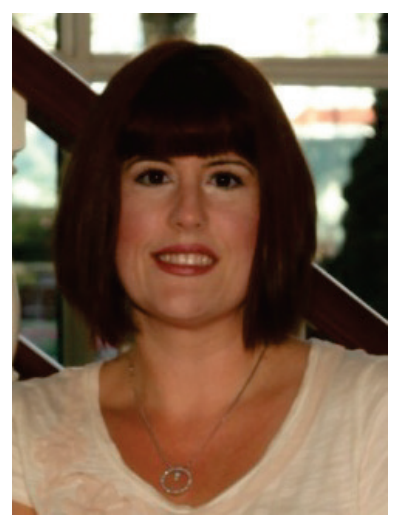

Dr. Nicole A. Buzzetto-More is an Associate Professor, Program Coordinator, and the Assurance of Learning and Assessment Chair in the Department of Business at the University of Maryland Eastern Shore. She is also Director of the Maryland State Department of Education Program Affiliate for Business, Management, and Finance. She received doctorate and masters degrees from Columbia University and earned a post doctorate from Tulane University. She also earned a masters degree from the College of New Rochelle and a bachelor's from Marist College. She is a frequent invited presenter at conferences across the globe; is on the editorial board of several journals; has authored numerous publications; and has been recognized with awards from the American Distance Education Consortium, Global Digital Business Association, and the Informing Science Institute. Recently, she was named a Fellow of the Informing Science Institute. She published two books in 2007, Principles of Effective Online Teaching and Advanced Principles of Effective ELearning. In 2010 her third book The EPortfolio Paradigm: Informing, Educating, Assessing, and Managing with E-Portfolios was published by the Informing Science Press. She can be reached at nabuzzetto-more@umes.edu 


\section{Appendix}

\begin{tabular}{|c|c|c|c|c|}
\hline \multicolumn{5}{|c|}{ MARYLAND BMF CAPSTONE RUBRIC } \\
\hline $\begin{array}{l}\text { Expecta- } \\
\text { tions }\end{array}$ & Exceeds Expectations & Meets Expectations & $\begin{array}{l}\text { Almost meet expecta- } \\
\text { tions }\end{array}$ & $\begin{array}{l}\text { Unaccepta- } \\
\text { ble }\end{array}$ \\
\hline $\begin{array}{l}\text { Capstone } \\
\text { Proposal }\end{array}$ & $\begin{array}{l}\text { Clearly defines core question } \\
\text { and all learning activities. } \\
\text { Skillfully, demonstrates an } \\
\text { understanding of the theoreti- } \\
\text { cal support for the project. } \\
\text { Provides robust background } \\
\text { information and compelling } \\
\text { justification. Methodology } \\
\text { proposed logically supports } \\
\text { the core question Analyzes a } \\
\text { condition or situation of sig- } \\
\text { nificance as the basis for ex- } \\
\text { ploration \& reflection. } \\
\text { Thoughtful \& realistic time- } \\
\text { line included. }\end{array}$ & $\begin{array}{l}\text { Defines the core question } \\
\text { and learning activities. } \\
\text { Demonstrates an under- } \\
\text { standing of the theoreti- } \\
\text { cal support for the pro- } \\
\text { ject. Provides back- } \\
\text { ground information and } \\
\text { justification. Methodolo- } \\
\text { gy proposed addresses } \\
\text { the core question. Pur- } \\
\text { posed to analyzes a sig- } \\
\text { nificant. } \\
\text { Timeline included. Mi- } \\
\text { nor flaws with no omis- } \\
\text { sions. }\end{array}$ & $\begin{array}{l}\text { Attempts to define the } \\
\text { core question and learn- } \\
\text { ing activities Demon- } \\
\text { strates an attempt to } \\
\text { provide theoretical sup- } \\
\text { port for the project. } \\
\text { Some background in- } \\
\text { formation and attempt at } \\
\text { justification presented. } \\
\text { Presents a methodology. } \\
\text { Attempts to analyze a } \\
\text { condition or situation of } \\
\text { significance. Timeline } \\
\text { attempted. Multiple } \\
\text { flaws or minor omis- } \\
\text { sions. }\end{array}$ & $\begin{array}{l}\text { Components } \\
\text { are either } \\
\text { inadequate or } \\
\text { missing. Se- } \\
\text { rious flaws } \\
\text { present. Pro- } \\
\text { posal does } \\
\text { not come } \\
\text { close to meet- } \\
\text { ing expecta- } \\
\text { tions. }\end{array}$ \\
\hline $\begin{array}{l}\text { Perceived } \\
\text { Difficulty/ } \\
\text { Effort \& } \\
\text { Thorough- } \\
\text { ness of Pro- } \\
\text { ject }\end{array}$ & $\begin{array}{l}\text { The project is clearly chal- } \\
\text { lenging, requiring a sizable } \\
\text { effort and commitment on the } \\
\text { part of the student; is multi- } \\
\text { faceted and complex and will } \\
\text { require the student to imple- } \\
\text { ment/explore multiple pro- } \\
\text { gram concepts. The project } \\
\text { represents a culmination of } \\
\text { learning. }\end{array}$ & $\begin{array}{l}\text { The project is challeng- } \\
\text { ing, and will require } \\
\text { effort and commitment } \\
\text { on the part of the stu- } \\
\text { dent. The project will } \\
\text { require the student to } \\
\text { implement/explore pro- } \\
\text { gram concepts. Minor } \\
\text { improvements needed } \\
\text { with no omissions }\end{array}$ & $\begin{array}{l}\text { The project attempts to } \\
\text { require the student to } \\
\text { implement/explore pro- } \\
\text { gram concepts. The pro- } \\
\text { ject attempts to repre- } \\
\text { sents a culminating expe- } \\
\text { rience. Flaws and omis- } \\
\text { sions evident. Greater } \\
\text { effort, level of difficulty, } \\
\text { and or thoroughness } \\
\text { required. }\end{array}$ & $\begin{array}{l}\text { Insufficient. } \\
\text { The difficul- } \\
\text { ty, level of } \\
\text { effort, and/or } \\
\text { thoroughness } \\
\text { are inade- } \\
\text { quate. }\end{array}$ \\
\hline Writing & $\begin{array}{l}\text { Skillfully uses precise and } \\
\text { descriptive language that clar- } \\
\text { ifies and supports intent and } \\
\text { establishes an authoritative } \\
\text { voice. Demonstrates correct } \\
\text { use of grammar, usage, punc- } \\
\text { tuation, mechanics, syntax, } \\
\text { sentence structure, and } \\
\text { spelling. }\end{array}$ & $\begin{array}{l}\text { Uses language that clari- } \\
\text { fies and supports intent. } \\
\text { Demonstrates control of } \\
\text { grammar, usage, punctu- } \\
\text { ation, mechanics, syntax, } \\
\text { sentence structure, and } \\
\text { spelling. Minor flaws }\end{array}$ & $\begin{array}{l}\text { Attempts to use language } \\
\text { that clarifies and sup- } \\
\text { ports intent. Attempts to } \\
\text { control of grammar, } \\
\text { usage, punctuation, me- } \\
\text { chanics, syntax, sentence } \\
\text { structure, and spelling } \\
\text { with some errors clearly } \\
\text { evident. Multiple correc- } \\
\text { tions and/or improve- } \\
\text { ments needed. }\end{array}$ & $\begin{array}{l}\text { Numerous } \\
\text { flaws. A seri- } \\
\text { ous rewrite is } \\
\text { required. }\end{array}$ \\
\hline
\end{tabular}




\begin{tabular}{|c|c|c|c|c|}
\hline $\begin{array}{l}\text { Quality of } \\
\text { Presenta- } \\
\text { tion } \\
\text { (See sepa- } \\
\text { rate grading } \\
\text { criteria) }\end{array}$ & $\begin{array}{l}\text { The presentation is profes- } \\
\text { sional in style, color, format, } \\
\text { and overall design. Slides are } \\
\text { neither empty or cluttered. All } \\
\text { required slides are included. } \\
\text { The presentation is includes } \\
\text { citations and is free from er- } \\
\text { rors. The content is clear, } \\
\text { complete, \& demonstrates an } \\
\text { ability to critically analyze } \\
\text { concepts. Exemplary verbal } \\
\text { and non-verbal skills are em- } \\
\text { ployed (see separate criteria). } \\
\text { The presentation is extempo- } \\
\text { raneous with any reading of } \\
\text { content, indicating prior prac- } \\
\text { tice. Student wears profes- } \\
\text { sional attire. }\end{array}$ & $\begin{array}{l}\text { Presentation is for the } \\
\text { most part professional in } \\
\text { style, color, format, and } \\
\text { overall design; has cita- } \\
\text { tions and is not plagia- } \\
\text { rized. The presentation } \\
\text { is mostly free from er- } \\
\text { rors in spelling, gram- } \\
\text { mar, word usage, and } \\
\text { punctuation. The content } \\
\text { is clear, and indicates an } \\
\text { effort to analyze con- } \\
\text { cepts. Mostly, appropri- } \\
\text { ate verbal and non-verbal } \\
\text { communications is em- } \\
\text { ployed. The presentation } \\
\text { is extemporaneous. Stu- } \\
\text { dent wears professional } \\
\text { attire. Minor flaws exist } \\
\text { in one or more areas. }\end{array}$ & $\begin{array}{l}\text { Presentation attempts to } \\
\text { be professional. The } \\
\text { presentation attempts to } \\
\text { employ proper mechan- } \\
\text { ics; however, errors are } \\
\text { evident. Attempt is made } \\
\text { to have content that is } \\
\text { clear, and indicates an } \\
\text { effort. Attempt at appro- } \\
\text { priate verbal and non- } \\
\text { verbal communications } \\
\text { is employed. Multiple } \\
\text { flaws exist in one or } \\
\text { more areas. }\end{array}$ & $\begin{array}{l}\text { Presentation } \\
\text { ineffective } \\
\text { due to serious } \\
\text { flaws in ei- } \\
\text { ther presenta- } \\
\text { tion design or } \\
\text { delivery. }\end{array}$ \\
\hline $\begin{array}{l}\text { Adherence } \\
\text { to Proposed } \\
\text { Delivera- } \\
\text { bles \& } \\
\text { Schedule }\end{array}$ & $\begin{array}{l}\text { Student continuously meets } \\
\text { all project deliverables in } \\
\text { accordance with planned } \\
\text { timeline. Student is clearly } \\
\text { able to organize his/her time } \\
\text { appropriate to the project. }\end{array}$ & $\begin{array}{l}\text { Student meets most pro- } \\
\text { ject deliverables in ac- } \\
\text { cordance with planned } \\
\text { timeline. Student is usu- } \\
\text { ally able to organize } \\
\text { his/her time appropriate } \\
\text { to the project. Minor } \\
\text { difficulties evident on } \\
\text { one or two occasions. }\end{array}$ & $\begin{array}{l}\text { Student attempts to meet } \\
\text { project deliverables. } \\
\text { Student attempts to or- } \\
\text { ganize his/her time ap- } \\
\text { propriate to the project. } \\
\text { Multiple issues meeting } \\
\text { deliverables on schedule. }\end{array}$ & $\begin{array}{l}\text { Student ex- } \\
\text { hibits poor } \\
\text { planning and } \\
\text { time man- } \\
\text { agement } \\
\text { throughout } \\
\text { project com- } \\
\text { pletion. }\end{array}$ \\
\hline $\begin{array}{l}\text { Overall } \\
\text { Quality of } \\
\text { Project }\end{array}$ & $\begin{array}{l}\text { Clearly defines the core ques- } \\
\text { tion and the learning activi- } \\
\text { ties. Supports the core ques- } \\
\text { tion with an analysis of rele- } \\
\text { vant and accurate evidence. } \\
\text { Elaborates on significance of } \\
\text { new knowledge acquired and } \\
\text { makes insightful connections } \\
\text { to hypothesis. Analyzes a } \\
\text { condition or situation of sig- } \\
\text { nificance as the basis for re- } \\
\text { flection. Makes connections } \\
\text { between personal ideas \& } \\
\text { experiences and more abstract } \\
\text { aspects of life, leading to new } \\
\text { perspective or insights. Is } \\
\text { focused on topic. Maintains } \\
\text { focus. Provides audience with } \\
\text { something provocative to } \\
\text { think about. }\end{array}$ & $\begin{array}{l}\text { Defines the core question } \\
\text { and the learning activi- } \\
\text { ties. } \\
\text { Supports the core ques- } \\
\text { tion with analysis. Pre- } \\
\text { sents } \\
\text { new knowledge and } \\
\text { addresses thesis/topic. } \\
\text { Makes connections be- } \\
\text { tween ideas and experi- } \\
\text { ences. Provides a con- } \\
\text { clusion. Minor flaws } \\
\text { evident. }\end{array}$ & $\begin{array}{l}\text { Attempts to define a core } \\
\text { question, analyze find- } \\
\text { ings, and present a con- } \\
\text { clusion. } \\
\text { Attempts to makes con- } \\
\text { nections between ideas } \\
\text { and experiences. } \\
\text { Conclusion attempted } \\
\text { but may be flawed. A } \\
\text { number of improvements } \\
\text { required in order to en- } \\
\text { hance the overall quality } \\
\text { of the project. Project } \\
\text { meets minimal require- } \\
\text { ments but falls short of } \\
\text { expectations. }\end{array}$ & $\begin{array}{l}\text { Poor project } \\
\text { quality. }\end{array}$ \\
\hline
\end{tabular}

